\begin{abstract}
"Mircea cel Batran" Naval Academy Scientific Bulletin, Volume XX - 2017 - Issue 2
The journal is indexed in: PROQUEST / DOAJ / Crossref / EBSCOhost/ INDEX COPERNICUS/ OAJI / DRJI / JOURNAL INDEX / I2OR / SCIENCE LIBRARY INDEX / Google Scholar / Academic Keys / ROAD Open Access I Academic Resources / Scientific Indexing Services I SCIPIOI JIFACTOR
\end{abstract}

\title{
LANGUAGE LEARNING AND MOBILITY WITHIN EUROPE
}

\author{
Alina BALAGIU ${ }^{1}$ \\ Carmen ZECHIA ${ }^{2}$ \\ ${ }^{1}$ Associate Professor PhD Electrical Engineering and Naval Electronics Department, "Mircea cel Batran" \\ Naval Academy, no 1, Fulgerului street, Constanta, alinabalagiu@yahoo.com \\ ${ }^{2}$ Senior Lecturer PhD Dana Naval Engineering Department, "Mircea cel Batran" Naval Academy, no 1, \\ Fulgerului street, Constanta.
}

\begin{abstract}
We have had the opportunity to take part at the International Conference on Moocs, language learning and mobility hosted by Universita degli Studi L'Orientale, Napoli, Italy, where teachers from Secondary Schools, researchers and academic staff from 63 prestigious universities in Europe gathered to debate and find solutions for language learning, multilingualism and intercomprehension for students' mobility stages. Some of the initiatives are going to be presented in this paper, as the Naval Academy is involved in Erasmus mobility programme having students coming and going to and from different countries.
\end{abstract}

Keywords: language learning, mobility, academic knowledge, skills, academic texts.

\section{Introduction}

Language learning is still debated by linguists, professors, and teachers in order to help students integrate in the Mobility Programs all over the European Union. One of the latest projects involving language learning, multilingualism and intercomprehension is MOVE-ME. The main objective of the project is to facilitate students' integration when they are in countries where they cannot speak their mother tongue. Developing students' ability to learnhow to learn is another objective of the programas long as the number of students moving throughout Europe is increasing and not always they can integrate into the new learning system. If for the last forty years English language has been the instrument that has gathered people all over the world, we can witness nowadays a new trend that implies helping especially young people to learn at universitiesin other countries in the language of the country they choose to improve their academic knowledge in. Students are encouraged to engage in interactive and communicative activities on forums, chats and videoconferences both in English and in the other language, in the case of this project the language is Italian. The project aims to create a learning path designed for students involved in mobility programs in order to help them gain the skills and competences for understanding and producing academic texts.

The Italian project that acted as the base of the eventhas specific aims for language learning that we try to summarize below:

- Increase students' awareness of the language learning process and knowledge of effective learning strategies;

- Improve the quality of oral and written skills of the students;
- Increase students' listening skills and understanding of written texts related to specific disciplines;

- Improve students' performances at oral and written examinations in the second language;

- Sustain students in learning how to learn;

- Provide syllabus for developing materials for learning languages for academic purposes using ICT.

\section{Mobility within Europe}

Not only Italians but all the nations and universities involved in mobility programmes struggle to improve the teaching quality, the syllabus and develop materials, most of them internet related, in order to attract students first and then help them to study either in English or the language of the country they are in within the project.

There were debates in several thematic areas of interest:

- Information and communications technology (ICT) tools;

- Content and Language Integrated Learning (CLIL) practices;

- Intercultural education in virtual classes;

- Gamification;

- Educational assessment;

- Language for Specific Purposes (LSP) or English for Academic Purposes (EAP);

- Multilingualism, intercomprehension and intercultural training.

a. ICT means Information and communications technology - or technologies involving computers, digital television, cell phones and other technological tools that cannot be ignored for language learning nowadays.

The author of a paper (Emma Abbate Liceo Statale Manzoni di Caserta, Italy) described the 


\section{"Mircea cel Batran" Naval Academy Scientific Bulletin, Volume XX - 2017 - Issue 2 \\ The journal is indexed in: PROQUEST / DOAJ / Crossref / EBSCOhost/ INDEX COPERNICUS/ OAJI / DRJI /}

JOURNAL INDEX / I2OR / SCIENCE LIBRARY INDEX / Google Scholar / Academic Keys / ROAD Open Access I Academic Resources I Scientific Indexing Services I SCIPIOI JIFACTOR

experience of designing and developing an elearning project platform (www.educlil.eu) by using cloud environment for co-operation. It also shows the "side effects" of an ICT learning environment.

Silvia-Adriana Apostol, Romania, emphasized the technological component of the practical courses of computer-assisted translation (CAT) and gives as alternative to translation tools, which are quite expensive for some universities, the free cloudbased technologythat can be used for educational purposes as long as they are compatible with smart phones and tablets.

Lorena Aguado Sánchez and Laura Ordóñez Rodríguez from SpanishviaSkype Spainare in favor of another ICT tool: Skype communication over the Internet, which includes voice, video, and instant message capabilities, in the ELE (Spanish as a Foreign Language) classroom in order to prepare students to pass the DELE ${ }^{\circ}$ exam (Diploma in Spanish as a Foreign Language). The project uses one-on-one Spanish lessons on Skype $($ ) to prepare foreign students from all around the world to pass this test (levels A2, B1, B2 and C1). The aim is the exams to be taken also on Skype for all the levels requested by the students.

The paper Online library (Raffaella Fiorini Université Paul-Valéry, France) offers another perspective on teaching and learning English by using the library online with the book trailers written by students and also using blogs for exchanging ideas and materials between students.

b. Content and Language Integrated Learning (CLIL) practices were developed by Alice Barana, Marina Marchisio, Department of Mathematics, the University of Torino, Italy, who proposed a model of teacher training CLIL methodology. The training phase involves problem solving, problem posing and the use of a Virtual Learning Environment both as a student and as a teacher. The base of the project is producing interactive materials and using them in sharing experiences and preparing teachers and students in debating real-world problems.

Within the paper Investigating the potential of a MOOC on technologies for CLIL in teacher training the authors (Letizia Cinganotto INDIRE, and Daniela Cuccurullo ITT Giordani Striano Naples, Italy) describe the main features of a fiveweek free international MOOC on CLIL and technologies, online project that used during the course in particular Twitter, Telegram and YouTube and was attended by 5000 participants in 2016 and 2017.

c.Intercultural education in virtual classes

The advantages and disadvantages of virtual classroom involving instructive-formative activities that can change the teacher and student perspective upon learning becoming more efficient than what we have experienced before are highlighted by Irina -Alexandra Bîrsănescu and Călin Răzvan -Alexandru University of Craiova, Romania, in the paperVirtual reality, augmented reality and mixed reality trends in pedagogy.

d. Multilingualism, intercomprehension and intercultural training was debated by Irina David from The Bucharest University of Economic Studies, Romania, within the paper Autonomous enhancement of communication skills in foreign languages - a blended learning approach. The aim of the author is to emphasis the advantages of a blended learning approach in the field of foreign language teaching/ learning, with special focus on learners' autonomy. The project Oportunidance - Dance Your Way to Other Cultures ERASMUS+ project, tries to help adult learners in their effort of learning a foreign language in order to increase their chances in the multilingual society. The tools used in order to develop the participants skills are a Moodle platform with language lessons in five languages, a Facebook page with dance tutorials with instructions in the five languages and events where people can communicate with each other.

\section{CONCLUSION}

All over Europe, the Universities involved in multinational projects like Erasmus, strive to facilitate learning for the incoming students in order to augment their chances to better understanding and from here better education. Besides using English as "lingua franca" MOOC offers online courses in other languages (Italian) designed for self-study. University students and staff have as main purposes intercomprehension and multilingualism and intercultural training in a Europe open to educate teenagers, young people and even seniors by means of Information and communications technology.

\section{BIBLIOGRAPHY}

Book of abstracts for the International Conference "MOOCs, Informal Language Learning, and Mobility" 